\title{
Geoeconomics in the light of International Political Economy: a theoretical discussion
}

\author{
A geoeconomia à luz da economia \\ politica internacional: uma discussão teórica
}

BRUNA COELHO JAEGER $* * *+$
PEDRO VINICIUS PEREIRA BRITES ${ }^{+++}$

\begin{abstract}
RESUMO: Tendo em vista o caráter interdisciplinar do campo da EPI, este artigo tem como objetivo central analisar o campo teórico da geoeconomia, que é entendida aqui como o estudo dos efeitos e das causas materiais das disputas de poder entre diferentes atores sobre a ordem internacional. A fim de realizar esta interconexão entre os dois campos analíticos, verificando-se a convergência com a EPI, explora-se os paralelismos e oposições entre as vertentes teóricas da geopolítica clássica e do marxismo, que são abordagens tradicionais dentro da EPI. Ademais, são discutidos os conceitos de Braudel e de Gottmann como visões alternativas e essencialmente geoeconômicas.
\end{abstract}

PALAVRAS-CHAVE: Geoeconomia; economia política internacional; geopolítica; marxismo.

ABSTRACT: Given the interdisciplinary nature of the field of IPE, this article aims to analyze the theoretical field of Geoeconomics, which is understood here as the study of the effects and the material causes of power disputes between different actors on the international order. In order to achieve this interconnection between the two analytical fields, checking the convergence with the IPE, it explores the parallels and oppositions between the theoretical aspects of Classical Geopolitics and Marxism, which are traditional IPE approaches. In addition, the concepts of Braudel and Gottmann are discussed as alternative and essentially geoeconomic views.

KEYWORDS: Geoeconomics; International Political Economy; Geopolitics; Marxism. JEL Classification: F59.

\footnotetext{
"Professor of International Relations at LaSalle University Center - UniLaSalle-RJ, Rio de Janeiro/RJ, Brasil. E-mail: brunacjaeger@gmail.com. ORCID https://orcid.org/0000-0002-7776-7213.

"* PhD candidate in International Political Economy at Universidade Federal do Rio de Janeiro (PEPIUFRJ). CAPES Fellow. Master in International Strategic Studies from Universidade Federal do Rio Grande do Sul (PPGEEI-UFRGS) and Bachelor in International Relations (UFRGS).

+ Professor of International Relations course at Fundação Getúlio Vargas - FGV-SP, São Paulo/SP, Brasil. Email: pvbrittes@gmail.com. ORCID: https://orcid.org/0000-0002-3013-2616

${ }^{++} \mathrm{PhD}$ in International Strategic Studies from Universidade Federal do Rio Grande do Sul (PPGEEIUFRGS), Master in International Strategic Studies (PPGEEI-UFRGS) and Bachelor in International Relations (UFRGS). Submitted: 10/September/2018; Approved 25/April/2019
} 


\section{INTRODUCTION}

The objective of this article is to analyze Geoeconomics, as a research agenda, verifying the convergence with the International Political Economy (IPE), due to the economic, political and strategic value of the geographic spaces. In this sense, the aim is to contribute to the advancement of the interdisciplinarity of IPE, whereas the gap pointed out by Susan Strange (1970) between International Relations and the International Economy. Geoeconomics is defined as the study of the effects and the material causes of power disputes among different actors on the international order, justifying their importance of analysis within the IPE. Nevertheless, conceptually, geoeconomics encompasses a significant number of contested visions, which result from the fact that it is a research agenda still under construction.

In order to achieve this interconnection between the two analytical fields, this research intends to explore, in its own way and within its limitations, Geoeconomics and its relations with the parallels and oppositions between the theoretical aspects of Classical Geopolitics and Marxism, which are traditional approaches that dialogue with IPE. Although they constitute radically different fields, it is possible to identify convergences from the "materialistic, unicausal and teleological" view of the history they both present (Mello 1999, 33). The methods of analysis of geographic causality (inserted in the context of classical geopolitics) and historical materialism (within the scope of Marxism and the theory of imperialism ${ }^{1}$ ) may be important interconnection elements between Geoeconomics and IPE. While the former analyze world history in the light of geographic phenomena, for the latter, it is the economic factors and their contradictions that determine social and international relations.

Despite the influences that both sides have on Geoeconomics, it is not possible to make it a pure result of the interconnection between Geopolitics and Marxism. In this sense, the Braudelian theory, when analyzing the history of social dynamics from the long term (geographical coercion being one of the main elements), as well as the concept of territory developed by Gottmann (1975), which correlates space, economic power and political organization, are also approaches that also adequately link Geoeconomics to IPE.

To achieve your goals, this article is divided into three sections. In the first one, we present the theoretical field of Geoeconomics, definitions, debates and main analytical aspects. Next, the parallels and oppositions between classical geopolitics and historical materialism are undertaken as different ways of understanding IPE. The third section, finally, synthesizes Geoeconomics from this debate, and also

\footnotetext{
${ }^{1}$ Although there are perspectives that do not consider the existence of Theories of Imperialism, considering that the analyzes of Imperialism are, in fact, only a myriad of historiographic and analytical debates, for the purposes of this text, it is considered that the works of Rudolf Hilferding, Rosa Luxembourg, Karl Kautski, Nicolai Bukharin and Vladimir Ilitch Lenin compose a theoretical instrument on the phenomenon of imperialism. Thus, this heterogeneity composes the "Classical Marxist Theory of Imperialism" (Leite 2014).
} 
presents the concepts of Braudel and Gottmann as alternative and essentially geoeconomic visions.

\section{ANALYTICAL BASES OF GEOECONOMICS: ANALYSIS METHODS AND STATE PRACTICES}

Geoeconomics as a field of knowledge comes from classical geopolitics. In more specific terms, it can be understood as an extension of the sphere of geopolitics applied to international economic relations. In this sense, Geoeconomics is an unfolding of geopolitics. From a contemporary perspective, geopolitics refers to the analysis of the distribution and configuration of power in the International System and its effects on inter-state relations of international politics, as well as on the strategic morphology of the world space. Both geopolitics and geoeconomics are intrinsically linked to interstate geostrategic competition. However, Geoeconomics restricts the field of analysis of geopolitics and emphasizes the relevance of economic power as a factor of analysis. In this sense, it incorporates a special type of geopolitical competition.

The term "geoeconomics" was first used by Edward Luttwak in 1990. From the article "From Geopolitics to GeoEconomics: Logic of Conflict, Grammar of Commerce," the author assesses the United States' position on the economic and trade threat which represented Japan at the global level. In analytical terms, the author transposes the logic of military competition into the sphere of international trade. In this way, it observes economic capacities as an element of power, diagnosing the advent of Geoeconomics as a new perspective for the understanding of international disputes. In other words, in a post-Cold War perspective, the elements of power that were considered central to classical geopolitics would have given way to the economic factor. The configuration of power in the International System would depend on the geoeconomic distribution.

It should be noted that, from this perspective, it does not mean that economic factors had no relevance in classical geopolitical analysis, but rather, they were viewed as a means to achieve a particular condition of primacy. Economic power was understood as a mechanism for obtaining resources of power, such as war power, for example. From a geoeconomic perspective, economic factors are configured as power resources per se, transforming the logic of power distribution and the interstate competition profile.

Sanjaya Baru (2012) considers that Geoeconomics has a double analytical sense. On the one hand, it assesses the geopolitical implications of the economic phenomenon; on the other, it analyzes the economic effects of geopolitical trends. Giovanni Grevi $(2011,28)$ understands that Geoeconomics "encompasses both the conversion of economic assets into political influence and the mobilization of political power to achieve economic objectives through competitive or cooperative instances."

Economic power, within the analytical framework of Geoeconomics, is central to making geopolitical power sustainable. Both the maintenance of the military 
force, the diplomatic apparatus, the intelligence services, among others, are conditioned by the exercise of economic power. Following this traditional perspective of the geopolitical economy, Zakaria (1999) assesses the importance of budget appropriation for the conversion of wealth into effective geostrategic power. Condensing these perspectives, it is observed that a geoeconomic strategy is based, therefore, in the use of the economic resources for political ends, although of that use can bring economic gains.

Geoeconomics, therefore, does not overlap with traditional geopolitics, since it includes and amplifies the economic dimension as a strategic aspect. Geoeconomics intersects means and ends of the economic and geopolitical spheres. It is worth mentioning the use of economic power within the geopolitical logic by the states is not an advent of the post-Cold War period. This profile of behavior can be observed since the seventeenth century, as mercantilism evidences ${ }^{2}$.

The use of economic instruments to promote and defend national interests, as well as to produce profitable geopolitical results is the synthesis of what is Geoeconomics. For Blackwill and Harris (2016), Geoeconomics is placed on the one hand as a method of analysis and, on the other hand, as state practice. Geoeconomics deals with the analysis of how a state develops and exercises power from the economic perspective rather than the strictly geographical perspective. A structuring aspect of this perspective is that while geopolitics would traditionally be a zero-sum game, in Geoeconomics the sum would be positive. Thus, Geoeconomics combines the logic of geopolitics with economic tools.

The perception that the economy gains a new dimension in the distribution of global power places the disposition of economic resources as a central factor in understanding the status of interstate competition. In practical terms, the direction of the investment flow, as well as the pattern of trade, determine adjacent geopolitical power relations. In this sense, there is a juxtaposition of economic aspects that end up biasing classical geopolitics.

\section{CONVERGENCES AND OPPOSITIONS BETWEEN HISTORICAL MATERIALISM AND GEOGRAPHICAL CAUSALITY}

The objective of this section is to present the main conceptual aspects of classical geopolitics and Marxism, in order to give subsidy to the subsequent analysis of Geoeconomics in IPE. In this way, the correlations and divergences between the geographical causality (or determinism) of authors such as Ratzel, Mahan and, especially, Mackinder, in relation to materialism as motor of world history present

\footnotetext{
${ }^{2}$ At the time of mercantilism, France and England, notably the greatest rival powers of the period, sought to equate in terms of power and wealth. In this sense, to defend themselves from rival expansionism, mercantilism emerges as a genuinely geoeconomic instrument to respond to the challenges posed by a system of threats, that is, by which material reproduction appeared as a strategic problem.
} 
in Marx and in the theorists of imperialism are evidenced. According to Mello (1999), there is an unusual parallelism that can be observed between the geographic materialism of classical geopolitics and Marx's historical materialism. In analyzing Halford Mackinder's theory, the author points out that while geopolitical theorists condition history by geography, Marxists do so through economics. By this, "the virtue of classes or nations is inexorably subject to the fortunes of economic or geographic actors" (Mello 1999, 35).

The origin of geographical causation dates back to Friedrich Ratzel $(1897)^{3}$, considered the father of geopolitics and founder of the German determinist school ${ }^{4}$. According to the author, analyzing the imperialist expansion of the late nineteenth century, geographic factors influence the political fate of states in a determinant way. With strong influence of the natural sciences, Ratzel establishes the bases of the geographic determinism, being the man a product of the means through processes of selection and adaptation. The State, in this sense, should be seen as a biogeographic organism, with its own life and greater purpose of struggle for survival. It would be this "geographical sense" of the state that would motivate the search for expansion and conquest of space, the counterpart of which would be subjection or annihilation by other stronger states. However, Ratzel defends himself against the criticism of the French possibilist school, pointing out that this was not a narrow determinism, but a potential that depends on being effected. Rudolf Kjellen ${ }^{5}(1905)^{6}$, on the other hand, radicalizes Ratzel's thought as much as possible. Admittedly forerunner of the author's ideas, Kjellen analyzes the state as a living organism in space, but also "slave" of the territory. Alfred Mahan $(1890)^{7}$, in describing British sea power as an example to be followed by the United States, points out the geographic position, physical conformation and territorial extension as conditions for establishing sea power (besides large population, national character and nature of the government). In this way, like Halford Mackinder (1904), by means of geographical factors, Mahan demonstrates the two main pillars of the British external performance due to its insular position: search for expansion and balance of power in Eurasia.

Mackinder is regarded as one of the most influential thinkers of classical geo-

\footnotetext{
${ }^{3}$ In: Mello, Leonel I. A. (1999). Quem tem medo da geopolítica? São Paulo: Edusp/Hucitec.

${ }^{4}$ In opposition to the Ratzelian thought was created the French geopolitical school, whose greatest exponent was the author Vidal de La Blache, establishing the debate determinism versus possibilism in Political Geography.

${ }^{5}$ In criticizing the French possibilist school, he creates the term geopolitical (1899), differentiating it from political geography. While the former would be dynamic, strategic, and forward-looking, the latter would be static and descriptive. Space, in this sense, is seen by geopolitics from the point of view of the state, not the reverse as in political geography.

${ }^{6}$ In: Mello, Leonel I. A. (1999). Quem tem medo da geopolítica? São Paulo: Edusp/Hucitec.

${ }^{7}$ In: Mello, Leonel I. A. (1999). Quem tem medo da geopolítica? São Paulo: Edusp/Hucitec.

${ }^{8}$ In: Mello, Leonel I. A. (1999). Quem tem medo da geopolítica? São Paulo: Edusp/Hucitec.
} 
politics whose theory of terrestrial power and heartland ${ }^{9}$ influenced many of the strategies of the great powers in the twentieth century. The author innovates by analyzing the world as a closed political system in which the international order ceases to be a European concert to become a planetary system due to the rise of the United States and Japan in the early twentieth century. The author innovates by analyzing the world as a closed political system in which the international order ceases to be a European concert to become a planetary system due to the rise of the United States and Japan in the early twentieth century. In this international order, the historic struggle for supremacy between sea power and land power is in force ${ }^{10}$. Motivated by the fear of German expansion, Mackinder applies geographic causality to universal history to warn British leaders about the decline of sea power. From this perspective, the rise of terrestrial power would be the result of the advent of the closed political system and the technological innovations that allowed the greater integration of the spaces due to the railway advance ${ }^{11}$.

In this way, geographic materialism is evidenced by pointing to space, position, relief, climate and natural resources as the most constant factors in history ${ }^{12}$. Mello (1999) defines Mackinder's thinking as a "geographical realism", marked by pragmatism and the global view of disputes through geography applied to the great powers. Karl Haushofer ${ }^{13}$, German strategist of the III Reich, applies the ideas of Mackinder to defend an alliance between Germany and Russia like key to conquer

\footnotetext{
${ }^{9}$ Central region of Eurasia, more extensive plain of the globe, isolated from the outside world and inaccessible to maritime power. It favors the terrestrial power of the continental power that came to conquer it. It gave mobility to the nomadic-pastoral peoples of Central Asia to pressure Europe, resulting in its development and the Iberian naval expansion. It represents the historical-geographical correlation that bases the theory of terrestrial power.

10 The dispute between oceanism and continentalism would prove the recurring wars since antiquity. According to Mackinder, the terrestrial powers use their central position (inner lines) to expand to peripheral regions and to achieve exits to the sea, while the sea powers use their insular position (outer lines) to dominate coastal regions and to corral the terrestrial powers. Ex: Greco-Persian Wars, Peloponnesian War, Seven Years War, Napoleonic Wars, Great Game between England and Russia and Franco-Prussian War.

${ }^{11}$ In this sense, technological advances could neutralize the weight of certain geographical realities. Transcontinental railways should outpace the ship's mobility and the strategic position of the Suez Canal. The Berlin-Baghdad Railway evidenced the rise of Germany as land power as opposed to England, giving rise to a naval race that raised the former to amphibious power status. The threat to the balance of power and maritime supremacy of England was what resulted in the alliance with Russia and France in the early twentieth century.

${ }^{12}$ In this conception, geography would define the national character (sea, continental or amphibian vocation), establishing the secular confrontation between the oceanic powers and the continental ones. Portugal, Spain and England would be the leading countries in the first group, predestined to naval and mercantile activities; while Germany and Russia of the latter, with expansionist tendencies; and the United States and France of the third, with a hybrid character of development, according to which it alternated or concurrently adopted the two vocations.

${ }^{13}$ Founder of the Institute of Geopolitics at the University of Munich (1933). It defines Geopolitics as an autonomous branch of Political Science, emphasizing the relationship between the State and geography in the formulation of foreign policy.
} 
England. In this sense, it applies the interconnection between materialism, competitive dynamics and geographical factors by exalting Russia as a natural geopolitical ally that should be sought by Germany as a link to the heartland, and whose ideological divergences should be left aside.

In the period of the Cold War, Zbigniew Brzezinski (1986), strategist of American foreign policy, draws inspiration from Mackinder and incorporates the author's theory (though without making any explicit reference) to make an analysis of the bipolar confrontation that was intended to be realistic and non-ideological. In this way, it addresses the nature of the dispute as a confrontation between two geopolitical antagonists, which goes back to the historical and imperial opposition of an ocean power versus a terrestrial power. It would, therefore, be a rivalry of geopolitical and strategic order, largely conditioned by geographic factors, reducing the weight of economic and ideological aspects.

Despite the singularities of these theoretical aspects, it is possible to draw a convergence between the geographic determinism present in classical geopolitics and the Marxist method of historical materialism. While for the former the historical processes are conditioned to the geographical realities,

Schematically, the Marxist conception has as irreducible foundation the determination of the economic base on the political-ideological superstructure, the class struggle between owners of the means of production and the labor force, the destruction of the capitalist system by the proletarian revolution and the construction of a future communist society (Mello 1999, 33) ${ }^{14}$.

In Marx's work, historical materialism determines that power relations are based on the social relations of production, that is, on the economic contradictions between the bourgeoisie and the proletariat. In this sense, a parallel could be defined, according to which, the accumulation of power (concept not analyzed by Marx) would come from the accumulation of income by the bourgeoisie, which always seeks to expand its surplus (surplus value) (Serrano 2014). It is precisely this search for expansion that determines the capitalist cycle of material reproduction (Aron 1982). The composition of the relations of production forms the economic structure of society, which determines its legal and political, as well as social consciousness. The mode of production of material life thus determines the development of social, political, and intellectual life. Through this, whereas in classical geopolitics are the geographical factors (secular conflict between oceanic and continental powers, for example, present in Mackinderian theory), in Marx, are the class conflicts that condition historical processes. "Men make their own history, but they do not do as they wish; they do not do so under the circumstances of their

\footnotetext{
${ }^{14}$ Our translation. Original extract "Esquematicamente, a concepção marxista tem como fundamento irredutível a determinação da base econômica sobre a superestrutura político-ideológica, a luta de classes entre proprietários dos meios de produção e detentores da força de trabalho, a destruição do sistema capitalista pela revolução proletária e a construção de uma futura sociedade comunista” (Mello 1999, 33).
} 
choice, but under those they face directly, linked and transmitted by the past" (Marx, "O 18 Brumário de Luís Bonaparte", 25)15.

One of the most remarkable aspects of Marxism is the holistic theory of modes of production. History is conceived as a succession of means of production, including capitalism, in which each of these periods is characterized by specific laws, always being defined by class relations, which are inherently conflictual. "Class relations that define a mode of production are those which, in each case, allow those who control modes of production to extract a surplus from the direct producers according to a mode proper to that mode of production" (Holmstrom 2014, 345). But more importantly,

A mode of production or a particular industrial phase is always linked to a particular form of cooperation and to a particular social stage, and [...] this form of cooperation is itself a 'productive force'; it follows that the set of productive forces accessible to men conditions the social state (Marx and Engels 1932 [2005], 55) ${ }^{16}$.

Marx, therefore, uses the method of historical materialism ${ }^{17}$ to analyze capitalist society and its future (Aron 1982). It investigates the contradictory and antagonistic character of capitalist society, with class struggle as its driving force present throughout history. The dynamics of inter-capitalist competition itself leads to interstate competition at a global level, materialized in many cases through colonialism. In a complementary way, technical progress appears in Marxist theory as a factor of exacerbation of the contradictions of capitalism, since they foster crisis of overproduction that would eventually lead to the proletarian revolution. There is a dialectic present in the search for geographic expansion with the purpose of shifting the limit of accumulation to avoid or bypass crisis of overproduction (Harvey 2005). Here it is possible to compare with the authors of classical geopolitics, especially Mackinder, who points out the importance of technological innovations to circumvent certain geographic realities. The mobility of transport, for example, would have been what allowed the overcoming of land power over the sea. Already in Marxist theory, the technologies of transport and communication become essential to the expansion of capital. This infrastructure ${ }^{18}$, present in

\footnotetext{
15 Our translation. Original extract: "Os homens fazem sua própria história, mas não o fazem como querem; não a fazem sob circunstâncias de sua escolha, e sim sob aquelas com que se defrontam diretamente, ligadas e transmitidas pelo passado" (Marx, "O 18 Brumário de Luís Bonaparte”, 25).

${ }^{16}$ Our translation. Original extract: "Um modo de produção ou uma determinada fase industrial estão sempre ligados a uma determinada forma de cooperação e a uma fase social determinada, e [...] essa forma de cooperação é, em si própria, uma 'força produtiva'; decorre disso que o conjunto das forças produtivas acessíveis aos homens condiciona o estado social Marx e Engels” 1932 [2005], 55).

${ }^{17}$ Historical materialism is a historiographic paradigm. Although it is a crucial element of Marxism, it cannot be confused with it.

${ }^{18}$ In every society there would be infrastructure as the economic basis of production relations, and the superstructure, that is, its legal and political institutions, as well as its ideological bases (Aron 1982).
} 
the production process itself, directly influences the geographic location of factories in large centers, in search of economies of agglomeration. Geography appears in Marxist theory, thus, as important to the theory of accumulation in the sense that it allows the displacement of capital to lower wages, as well as to override spacetime difficulties in production (Harvey 2005).

The temporal function of the credit system also allows this essential geographical expansion to capitalist accumulation, which in turn conforms to the uneven international division of labor. In the theory of imperialism, the relation of center-periphery power appears as an asymmetric economic relation, whose interstate conflicts would be determined by economic ends. Although Marx did not directly approach international relations, since the state was not the object of a theoretical systematization as is done in classical geopolitics, the global reach of capitalism is given from its expansionist and universalizing movement, as a modernizing and civilizing force (Nogueira and Messari 2005). In other words, conflicts and changes in the international system would be inherent in the class struggle. The theories of imperialism thus emerge as a form of application of Marx's theory and the method of historical materialism more directly to international relations. Hilferding (1910), in this sense, when analyzing financial capitalism as the last phase of capitalist development, defines imperialism as the movement of expansion of monopoly capital, that is,

Expansion policy, conquest and territorial domination in order to control sources of primary resources and ensure the widening of the range of capital valorization (by expanding the internal productive scale for exporting goods, or by exporting capital itself) (Corrêa 2011, 6) ${ }^{19}$.

In convergence with classical geopolitical theory, from the point of view of international politics, Lenin (1917) adopts states as the main actors of the international system, not social classes as postulated by Marx. This does not imply in obliterating that Lenin analyzed the role of the great conglomerates, which were essential to the expansion model of state monopoly capitalism, which was especially consolidated in the second half of the nineteenth century. By this way, the concept of unequal development to the class struggle in the international plane acquires own dynamics. The Theories of Imperialism thus incorporate analyzes of inter-state conflicts with different capacities, especially determined by economic factors, whereas in classical geopolitics aspects such as territory and position would be more decisive in international disputes. In the theory of imperialism, due to the exhaustion of territories capable of expansion, domination by financial capital assumes other forms, whose possibility of repartillation leads to the intensification of rivalries. In geopoli-

\footnotetext{
${ }^{19}$ Our translation. Original extract: Política expansionista, de conquista e dominação territorial com o fim de controlar fontes de recursos primários e garantir a ampliação do raio de valorização do capital (por meio da ampliação da escala produtiva interna para exportação de mercadorias, ou por meio da própria exportação de capital) (Corrêa 2011, 6).
} 
tics, in turn, threats are inherently domination and subjection by another stronger state, which determines territorial expansion as a way of survival.

Also, from historical-dialectical materialism, in "Economic History of Brazil," Caio Prado Jr. (1945 [2012]) revolutionized the study of economics and history. The author rehearsed a new periodization for the Brazilian economy and demonstrated the cyclical and dependent nature of the Brazilian agricultural export, dominant in the first four centuries of the country. In the opening chapters of the work, the author focuses on explaining with great detail the geographical and climatic aspects of Brazil. His approach is pioneering in the country by allying geography and politics to analyze the Brazilian structural backwardness. In this sense, following the Hegelian tradition, Caio Prado Jr. distinguishes the accidental aspects of the essential in Brazilian economic history, highlighting the long duration of the structural factors that would condition the position of Brazil in the international division of labour.

\section{GEOCONOMY IN INTERNATIONAL POLITICAL ECONOMY}

International Political Economy emerged as an analytical strand in the 1970s in response to the challenges posed by changes in the International System, especially those faced by US foreign policy ${ }^{20}$ (Fiori 2008). Susan Strange (1970), one of the founders of IPE, warns of the need to incorporate the economy into the analysis of the international order, in view of the perspective of relative decline of the nation-state as a global actor to the detriment of the market. The creation of the GATT and the IMF in this sense would represent a way of dealing with the increase of economic interdependence, since protectionist practices would have given rise to liberal competition (Cohen 2008). In other words, it sought to ensure that interstate disputes would focus on technical rather than security issues. However, soon the increase in interdependence was an intensifying factor of international conflicts. In this way, IPE presents itself as a form of analysis that interconnects economics and politics in the material world, the facts.

There is no consensus on what IPE is about, as there are many different links between Economics and International Relations. Even if the relationship among disciplinary groups is a relation of power, Geoeconomics exercises a necessary dialogue between the political and economic imperatives of the international system, incorporating it into IPE. In this sense, Geoeconomics is defined through the use of economic instruments to promote and defend national interests, as well as to generate beneficial geopolitical results (Blackwill and Harris 2016). From a complementary perspective, it is defined here as the study of the effects and the material

\footnotetext{
${ }^{20}$ IPE, in view of this context, has as a priority the following issues: the decline of the American economy; dollar crisis; economic recovery of Europe and Japan; increased imbalance of economic power among industrialized nations; invasion of Afghanistan by the USSR; decolonization and North-South asymmetry; oil shocks; Vietnam War; détente between US and USSR; stagflation; end of the Bretton Woods system (Cohen 2008).
} 
causes of power disputes among different actors on the international order, justifying their importance of analysis within the IPE.

In relation to the debate proposed in this research, Geoeconomics can be analyzed as a synthesis of the convergences and oppositions between classical geopolitics and Marxist materialism. It is worth mentioning that this synthetic condition is not completely satisfactory, since Geoeconomics conforms as an analytical part with potential characteristics and own methods, as it incorporates as a research agenda elements such as trade policy, investment policy, economic and financial sanctions, financial and monetary policy, energy and commodities, aid and cyber. It presents theoretical aspects that correlate to these two other traditional theoretical fields. Since Geoeconomics is viewed as a branch of geopolitics, the parallels to classical geopolitics are more evident. Geographic factors matter to the extent that they influence geoeconomic disputes and interactions. Decision-making on the geographic expansion of multinationals from territorial aspects, as well as processes of regional integration and cooperation among neighboring countries, for example, condense geographic, political and economic factors that make up Geoeconomics. However, unlike classical geopolitics, geographic causality is attenuated, therefore, without a deterministic conception involved in geoeconomic analyzes. Thus, perhaps unusually, Geoeconomics presents convergences with the method of historical materialism, in view of the determination of the economic elements as a means and purpose of the search for power. Although not a theoretical Marxist, it is possible to identify in the geoeconomic analysis several principles that are associated to each other. Marx's own scheme (M-C-M') can gain a geoeconomic reading through the need for geographic expansion of capital as an essential way to perpetuate the process of accumulation. In this sense, like mercantilism, imperialism also shapes itself as a geoeconomic system of power-seeking, in which geographical expansionism accompanies economic disputes.

Robert Kaplan (2013), American analyst, aligned with the perspective of "geographic realism", points out that geography is more conforming than determines international events. That is, it is not fatalistic about the role of geography. As well as the economic and military powers, therefore, the geographic factor would be an important limiting and instigator of the action of the States, which confers a geoeconomic definition in itself. In this way, the geographic elements would lead to a "determinism" partial more probabilistic than conditioning. Although there are a myriad of mutually combining determinants, the author emphasizes the weight of geography as the most permanent and fundamental element of international relations, constituting itself as a "preface to the very unfolding of human events" ${ }^{21}$ (Kaplan 2013, 29). By presenting an alternative

\footnotetext{
${ }^{21}$ According to the author: European civilization was born in Greece; Germany has become continental and militaristic power because of the lack of mountain ranges; the early democratic system in England because of its island position; in Africa, few natural harbors and few rivers navigable from the sea prevented greater contact with the Mediterranean civilizations; most of the world's poorest economies do not have access to the sea; bioceanic character of the US that allowed the isolation of the main zones
} 
reading to Kaplan, Maurício Metri (2017), when analyzing the correlation between the geopolitical imperative and the geoeconomic imperative in the dynamics of interstate competition, emphasizes geographic knowledge as strategic and, therefore, essential to the military exercise. Complementarily, the mobilization of economic resources necessarily accompanies the security policies of the states, constituting also as strategic to the movement of accumulation of power and wealth, and thus relating to space through war. In this sense,

Economic thinking became, therefore, permeated with geographic and strategic mindset. While the challenges themselves are the same for many of the central authorities, their geoeconomic initiatives are generally different. This is due, among other reasons, to the geography and territorial characteristics proper to each political unit and its respective economic territories (Metri 2017, 11)22.

Jean Gottmann (2012), also through a conception that can be understood within Geoeconomics, works the concept of territory as an organized space, in which geography appears as the element of interlocution with social dynamics. According to the author, the territory is defined through its social relations of domination and control, since it is fundamentally concrete, material and politicalideological. Although the author is not linked to Marxist historical materialism, he emphasizes the conflicting dynamics in the constitution of the territory as a movement, being characterized by it as "arena".

Territory is a portion of geographic space that coincides with the spatial extent of a government's jurisdiction. It is the physical container and support of the political body organized under a structure of government. It describes the spatial arena of the political system developed in a national state or a part of it that is endowed with a certain autonomy. It also serves to describe the positions in the space of the various units participating in any system of international relations. We can therefore consider the territory as an ideal connection between space and politics. Since the territorial distribution of the various forms of political power has profoundly transformed throughout history, territory also serves as an expression of the relationships between time and politics (Gottmann 1975 [2012], 523 $)^{23}$.

of conflict, as well as a universalist morality; the tendency of technological diffusion to occur at a common latitude due to similar climatic conditions (Kaplan 2013).

22 Our translation. Original extract: "O pensamento econômico torna-se, assim, impregnado de raciocínio geográfico e estratégico. Embora os desafios em si sejam os mesmos para diversas das autoridades centrais, suas iniciativas geoeconômicas são em geral distintas. Isto se deve, dentre outras razões, por causa da geografia e das características territoriais próprias de cada unidade política e de seus respectivos territórios econômicos” (Metri 2017, 11).

${ }^{23}$ Our translation. Original extract: “Território é uma porção do espaço geográfico que coincide com a extensão espacial da jurisdição de um governo. Ele é o recipiente físico e o suporte do corpo político 
This work sought to make a brief bibliographical review of authors and theories that help in the understanding of Geoeconomics as a branch of IPE. Nevertheless, the perspective of the French historian, Fernand Braudel (1969), is pointed out as an essentially geoeconomic examination of the composition of the analytical foundations of IPE. In analyzing the history of humanity, the author stresses the spatial imperative in all social phenomena. Like time, geography is given as a moving structure and, therefore, relates to humanity in a dynamic rather than static way. In his classic work, "The Mediterranean and the Mediterranean World in the Age of Philip II" (1949), Braudel emphasizes the interconnection among geography, demography, materialism and the environment. In this sense, its concepts of "geographical coercion" and "long duration" are fundamentally correlated. "I thus believe in the reality of a particularly slow history of civilizations, in their abyssal depths, in their structural and geographical features" (Braudel 1969, 25). That is, at different time scales, the long duration refers to a slow geographic time, while the medium-term cycles reveal systemic transformations in demography, economy, society and politics. The short term, in turn, would be the history of events, or occurrence.

Although dynamic in its own way, there is an almost immobile history of man's relationships with the environment around him, in which meaning is revealed only when great periods of time are embraced. The long duration would therefore be structural, constituting a high level of "unconscious history." The term "geographical coercion" is what synthesizes these aspects of quasi permanence in social dynamics, influencing the history of mankind as "long-term prisons" whose developments respond at a slow pace, and their transformations are usually gradual (Braudel 1969, 50).

Certain structures, because they live a long time, become stable elements of a multitude of generations: they clash with history, they bother it, therefore, they command the flow. Others are more ready to smash. But all are at the same time supporters and obstacles. Obstacles are marked as limits from which man and his experiences can not be liberated. [...] The most accessible example seems to be geographical coercion. For centuries, man is a prisoner of climates, of vegetation, of animal populations, of cultures, of a slowly constructed equilibrium, from which one can not deviate without the risk of everything again at stake (Braudel 1969, 49-50)24.

organizado sob uma estrutura de governo. Descreve a arena espacial do sistema político desenvolvido
em um Estado nacional ou uma parte deste que é dotada de certa autonomia. Ele também serve para
descrever as posições no espaço das várias unidades participantes de qualquer sistema de relações
internacionais. Podemos, portanto, considerar o território como uma conexão ideal entre espaço e
política. Uma vez que a distribuição territorial das várias formas de poder político se transformou
profundamente ao longo da história, o território também serve como uma expressão dos relacionamentos
entre tempo e política” (Gottmann 1975 [2012], 523).
${ }^{24}$ Our translation. Original extract: "Certas estruturas, por viverem muito tempo, tornam-se elementos
estáveis de uma infinidade de gerações: atravancam a história, incomodam-na, portanto, comandam-lhe
o escoamento. Outras estão mais prontas a se esfacelar. Mas todas são ao mesmo tempo sustentáculos
e obstáculos. Obstáculos, assinalam-se como limites dos quais o homem e suas experiências não podem 
Under Braudelian influence, "there is no social grouping at any point in history that has developed outside an accessible geographical space, and whose movements have not been influenced by the geography of where they were" (Metri 2017, $3)$. Despite the importance of geography in its analysis, its theory is not substantially geopolitical, but geohistorical, since it combines the relationship among individuals, societies and geographic space in time as the main object of reflection. Thus, besides being a strategic knowledge, geography is present in every social phenomenon, including economic relations and production. Through this, Braudel represents the greatest contribution to the interdisciplinarity of IPE, as well as a reading of its concepts through Geoeconomics.

\section{FINAL CONSIDERATIONS}

The objective of this work was to analyze the theoretical field of Geoeconomics, in a kind of state of the art of the discipline, verifying its convergence with IPE. The importance of this object of analysis lies in the fact that Geoeconomics still does not constitute itself as a consolidated theoretical field, although its practices date from the mercantilist period. In this sense, in spite of doing so in an incipient way considering the breadth of the debate, it was sought here to correlate the Geoeconomics and IPE, especially by the substantially interdisciplinary nature of the latter.

Through a brief bibliographical review, two traditional theoretical fields of IPE, classical geopolitics and Marxism, were approached in this essay in order to verify their parallels and divergences, assuming that this discussion is useful to understand the essence of Geoeconomics. According to the argumentative line mobilized throughout these pages, it is concluded that, despite being seen as a branch of geopolitics, Geoeconomics includes elements that can be analyzed both from the perspective of geographic causality and through the materialist method present in the Marxist approaches and Imperialism Theories. However, this debate does not in itself contain all the definitions of the analytical scope that refer to geoeconomic approach. Although there is a double movement of economic and geographic conditions, the Geoeconomics can be analyzed from the dynamics of power present in the history of the societies. In this way, we conclude, also presenting the Braudelian theory as a form of geoeconomic synthesis, which combines the geographic coercion present in the long duration with the social and economic phenomena that define the history of humanity. The theoretical effort to approach these different perspectives favors the elaboration of more comprehensive methods of analysis of the evolution of the economy and international politics.

libertar-se. [...] O exemplo mais acessível parece ainda o da coerção geográfica. Durante séculos, o homem é prisioneiro de climas, de vegetações, de populações animais, de culturas, de um equilíbrio lentamente construído, do qual não se pode desviar-se sem o risco de pôr tudo novamente em jogo." (Braudel 1969, 49-50). 


\section{REFERENCES}

Aron, Raymond (1992). As Etapas do Pensamento Sociológico. São Paulo/Brasília: Martins Fontes/ UNB.

Baru, Sanjaya (2012). "Understanding Geo-Economics and Strategy". Apresentado no seminário "A New Era of Geo-Economics: Assessing the Interplay of Economic and Political Risk" IISS Seminar, 23-25 de março de 2012.

Blackwill, R.D., Harris, J. (2016). War by Othermeans: Geoeconomics and Statecraft. Harvard, Belknep Press.

Braudel, Fernand (1969). Escritos sobre a História. São Paulo: Ed. Perspectiva.

Brzezinski, Zibgniew (1986). Game Plan: A Geostrategic Framework for the Conduct of the U.S.-Soviet Contest. Atlantic Monthly Press.

Cohen, Benjamin J. (2008). International Political Economy: An Intellectual History. Princeton: Princeton University Press.

Corrêa, Hugo F. (2011). O Status da Categoria Imperialismo na Teoria Marxista: Notas Preliminares a partir do Debate Clássico. NIEP/MARX.

Fiori, José L. (2005). “Economia Política Internacional e Teoria das Relações Internacionais”. Palestra realizada na Semana de Economia Política Internacional. Sala da Congregação da Faculdade de Economia e Administração da USP, em 12/09/2005, publicado em 08 de mar. 2008.

Gottmann, Jean (2012). "A evolução do conceito de território". Boletim Campineiro de Geografia. 2(3): 523-545.

Gottmann, Jean (1975). “The evolution of the concept of territory”. Social Science Information, 14(3): $29-47$.

GREVI, Giovanni (2011). “Geo-Economics and Global Governance”, in: MARTININGUI, Ana; YOUNGS, Richard (eds.), Challenges for European Foreign Policy in 2012: What Kind of Geo-Economic Europe? Madri: Fride.

Harvey, David (2005). A Produção Capitalista do Espaço. São Paulo: Annablume.

Kaplan, Robert (2013). A Vingança da Geografia. Rio de Janeiro: Elsevier.

Leite, Leonardo de Magalhães (2014). "Sobre as teorias do imperialismo contemporâneo: uma leitura crítica”. Economia e Sociedade, Campinas, v. 23, n. 2 (51), p. 507-534.

Lênin, Vladmir I. (1979). “Imperialismo Fase Superior do Capitalismo”. In: Obras escolhidas, v.1. São Paulo: Alfa-Omega.

Luttwak, Edward N (1990). "From Geopolitics to Geo-Economics: Logic of Conflict, Grammar of Commerce". The National Interest, 20: 17-23.

Marx, Karl (1852 [2011]). O 18 de Brumário de Luís Bonaparte. São Paulo: Boitempo.

Mello, Leonel I. A. (1999). Quem Tem Medo da Geopolítica? São Paulo: Edusp/Hucitec.

Metri, Mauricio (2017). "Imperativos Geoestratégicos: o (geo)político, o (geo)econômico e o (geo) monetário." Anais do $6^{\circ}$ Encontro da ABRI.

Nogueira, João P.; MESSARI, Nizar (2005). Teoria das Relações Internacionais. São Paulo: Elsevier.

Prado Jr., Caio (1945 [2012]). História Econômica do Brasil. Brasília: Editora Brasiliense.

Serrano, Franklin (2014). A Teoria do Valor de Marx: Excedente ou "Transfiguração Crítica"?. Em http://www.excedente.org/wp-content/uploads/2014/11/download-5.pdf.

Strange, Susan (1970). "International Economics and International Relations: A Case of Mutual Neglect”. International Affairs (Royal Institute of International Affairs 1944-), 46(2): 304-315.

Zakaria, Fareed (1999). From Weath to Power: The Unusual Origins of America's World Role. Princeton: Princeton University Press. 